Research Article

\title{
Epidemiologic Data of Vitamin D Deficiency and Its Implication in Cardio-Cerebrovascular Risk in a Southern Italian Population
}

\author{
Rocco Capuano, ${ }^{1,2}$ Federica Marchese, ${ }^{1}$ Raffaella Sica, ${ }^{1}$ Eduardo Capuano, ${ }^{1}$ \\ Marzia Manilia, ${ }_{1}^{1}$ Anna Grazia Iannone, ${ }^{1}$ Alessandro D'Ambrosio, ${ }^{2}$ Alvino Bisecco, \\ Gioacchino Tedeschi, ${ }^{2}$ Antonio Gallo, ${ }^{2}$ and Vincenzo Capuano $\mathbb{D D}^{1}$ \\ ${ }^{1}$ Cardiology Unit “G. Fucito” Hospital,Mercato San Severino, Azienda Ospedaliera Universitaria di Salerno, Salerno, Italy \\ ${ }^{2}$ Department of Advanced Medical and Surgical Sciences, University of Campania Luigi Vanvitelli, Napoli, Italy \\ Correspondence should be addressed to Vincenzo Capuano; federicamarchese86@libero.it
}

Received 7 January 2021; Revised 13 April 2021; Accepted 26 May 2021; Published 8 June 2021

Academic Editor: Roxana Valdés-Ramos

Copyright (c) 2021 Rocco Capuano et al. This is an open access article distributed under the Creative Commons Attribution License, which permits unrestricted use, distribution, and reproduction in any medium, provided the original work is properly cited.

\begin{abstract}
Background. Vitamin D $(25(\mathrm{OH}) \mathrm{D})$ deficiency is a prevalent condition worldwide. However, the highest prevalence rates of $25(\mathrm{OH}) \mathrm{D}$ deficiency have been attributed to regions with higher latitude. A close association between 25(OH)D and cardiocerebrovascular $(\mathrm{CCV})$ risk factors and major health problems has been identified. Aim. To establish the prevalence of $25(\mathrm{OH}) \mathrm{D}$ deficiency and to investigate the relationship between 25(OH)D levels and CCV risk factors (blood cholesterol, triglycerides, glucose concentrations, body mass index, and systolic and diastolic blood pressure) in a cohort representative of Southern Italy. Methods. The prevalence of 25(OH)D levels was evaluated in 1200 subjects aged 25-74 years (600 males and 600 females), enrolled in the "VIP" (from Italian for Irno Valley Prevention) Project, whereas multiple linear regression analysis was used to determine the relationship between 25(OH)D levels and CCV risk factors. Results. Only 13.3\% of females and $11.1 \%$ of males showed adequate serum concentrations of $25(\mathrm{OH}) \mathrm{D}(\geq 30 \mathrm{ng} / \mathrm{ml})$, while $59.3 \%$ of females and $55.1 \%$ of males showed $25(\mathrm{OH}) \mathrm{D}$ deficient levels $(<20 \mathrm{ng} / \mathrm{ml})$. We observed an independent association between $25(\mathrm{OH}) \mathrm{D}$ concentrations and metabolic syndrome score, LDL cholesterol, HDL cholesterol, and corrected QT (cQT). Conclusions. We report a high prevalence of 25(OH)D deficiency across the largest Italian adult population studied so far and, in particular, the first across Southern Italy; furthermore, we provide data on the association between $25(\mathrm{OH}) \mathrm{D}$ deficiency and higher CCV risk factors.
\end{abstract}

\section{Introduction}

Vitamin D plays an essential role in calcium homeostasis and bone metabolism, preventing rickets and osteomalacia [1-5]. Vitamin D is metabolized first to 25 hydroxyvitamin $\mathrm{D}(25(\mathrm{OH}) \mathrm{D})$ and then to the hormonal form 1,25-dihydroxyvitamin $\mathrm{D}\left(1,25(\mathrm{OH})_{2} \mathrm{D}\right)$. Moved by the ubiquitous expression of $1,25(\mathrm{OH})_{2} \mathrm{D}$ receptors, the active form of vitamin $\mathrm{D}$, researchers investigated the potential extraskeletal actions of vitamin $\mathrm{D}$, discovering its determinant role in the autoimmune, cardiovascular, and neurological systems [6-13]. Furthermore, epidemiological studies revealed the association between low $25(\mathrm{OH}) \mathrm{D}$ serum concentrations, the surrogate marker for vitamin D nutritional status, and chronic diseases related to oxidative stress, inflammation, and aging, such as diabetes, cancer, and cardiovascular (hypertension, heart attack) and neurological (stroke, multiple sclerosis, and Alzheimer's disease) diseases [14]. As a matter of fact, research conducted on the relationship between $25(\mathrm{OH}) \mathrm{D}$ and cardiovascular events [15-27] and cerebrovascular accidents $[28,29]$ highlighted the association between low serum 25(OH)D concentrations and cardio-cerebrovascular (CCV) risk factors.

Adequate serum concentrations of $25(\mathrm{OH}) \mathrm{D}$ range from 30 to $100 \mathrm{ng} / \mathrm{ml}$, while those lower than $20 \mathrm{ng} / \mathrm{ml}$ are $\mathrm{di}-$ agnostic of vitamin $\mathrm{D}$ deficiency. The said condition is typically caused by inadequate cutaneous synthesis, which is, in turn, strictly related to scarce exposure to sunlight 
$[30,31]$. To date, vitamin D deficiency is a prevalent health problem, among all ethnicities and age groups [32-35], which, hence, makes epidemiological studies essential to investigate the role of vitamin D in preventive and therapeutic strategies.

As far as Southern Italy is concerned, no epidemiological studies investigating vitamin $\mathrm{D}$ deficiency have been conducted among its population, although their 25(OH)D levels may be higher than those recorded in studies carried out in Northern Europe [14], due to lower latitude.

According to this background, we considered it of interest to evaluate the prevalence of vitamin D deficiency and its relationship with traditional CCV risk factors (blood cholesterol, triglycerides, glucose concentrations, body mass index, and systolic and diastolic blood pressure), in a representative Southern Italian cohort.

\section{Methods}

2.1. Study Design and Study Population. Data presented in this study are included in the 2018-2019 cross-sectional phase of the Irno Valley Prevention Project (VIP) [36], a randomized epidemiological and primary prevention study. Between January 2018 and July 2019, 1200 adults (aged 25-74 years), 600 males and 600 females, representative of the Irno Valley (Campania region), an area of Southern Italy, were randomly included from the electoral lists of two municipalities (Mercato S. Severino and Baronissi), following the rules of the Monica Project-MONICA Cardiovascular Diseases [37]. Three age and gender-matched lists of 120 subjects each were compiled. Firstly, an invitation letter was sent to the subjects in the first list. Then, in case of refusal, subjects were replaced with others from the second list and, in case of another refusal, with similar ones from the third list. The type of enrolment used allowed us to build the sample as initially planned: 120 males and 120 females per decade.

The local ethics committee approved the study, and participants provided their informed consent.

\subsection{Data Collection and Measurement. All patients under-} went a physician-administered medical history, clinical examination, electrocardiogram (ECG), and psychological assessment. Vascular risk factors and serum 25(OH)D were also measured. Body mass index (BMI) was calculated from height (in meters, using a wall altimeter) and weight (in kilograms, using a floor balance, SlimtronicRowenta ${ }^{\circledR}$ ), with subjects wearing light clothes. Two consecutive measurements of blood pressure at a 5-minute interval in the sitting position were performed according to the criteria of the World Health Organization [38] and the mean used in the study. Expired carbon oxide using the Micro Smokerlyzer (Bedfont Scientific Ltd, Rochester, UK) was used to assess the exposure to cigarette smoke. Levels of anxiety and depression were evaluated using the Italian version of the State-Trait Anxiety Inventory and the Italian version of the Beck Depression Inventory-II Edition.
2.3. Laboratory Assays. Blood samples were obtained, after an overnight fast, from the antecubital vein without venous congestion. The enzymatic method was adopted to determine total and HDL cholesterol, triglycerides, uric acid, C-reactive protein (CRP), and glycemia. LDL cholesterol was calculated with the Friedewald equation. Serum insulin was measured by a chemiluminescent method using Beckman Coulter Diagnostics DxI 800 analyzer (interassay $\mathrm{CV}<6 \%$ ).

Creatinine was measured using the kinetics-plugged method (500 nm) on Cobas-ABX automatic line, while C3 was measured by the nephelometric method on QM 300 method. Serum 25(OH)D concentrations were measured using the enzyme-linked immunosorbent assay technique (Immunoassay System Beckman Coulter). The vitamin D nutritional status was defined according to the Endocrine Society Guidelines: (1) adequate $\geq 30 \mathrm{ng} / \mathrm{ml}$, (2) insufficient $\geq 20$ and $<30 \mathrm{ng} / \mathrm{ml}$, (3) deficient $\geq 10$ and $<20 \mathrm{ng} / \mathrm{ml}$, and (4) severely deficient $<10 \mathrm{ng} / \mathrm{ml}[30,31]$.

2.4. Statistical Analysis. A Kolmogorov-Smirnov test was used to verify the normal distribution of demographic, clinical, and conventional MRI variables. The population was divided into 3 tertiles 25(OH)D:

Group 1: 400 subjects with $25(\mathrm{OH}) \mathrm{D}<15.1 \mathrm{ng} / \mathrm{ml}$

Group 2: 400 subjects with $25(\mathrm{OH}) \mathrm{D}$ within $\geq 15.1$ and $<22.4 \mathrm{ng} / \mathrm{ml}$

Group 3: 400 subjects with $25(\mathrm{OH}) \mathrm{D} \geq 22.4 \mathrm{ng} / \mathrm{ml})$

Across the three tertiles, we evaluated the differences in the following variables: age, height, weight, BMI, continuous metabolic syndrome score (calculated with both National Cholesterol Educational Program (NCEP) and International Diabetes Federation (IDF) methods [39]), systolic and diastolic blood pressure, HDL and LDL cholesterol, non-HDL cholesterol, triglycerides, glycemia, serum insulin, creatinine, C3, CRP, hemoglobin, white blood cells, carbon oxide, heart rate (HR), QRS, PR, QT, correct QT (cQT), depression, and anxiety. To compare quantitative variables among the 3 tertiles, we used one-way analysis of variance and the Bonferroni test. Chi-square analysis was used to test differences in prevalence. Moreover, to investigate independent associations between $25(\mathrm{OH}) \mathrm{D}$ and CCV risk factors, we carried out a multiple linear regression analysis (stepwise model), with $25(\mathrm{OH}) \mathrm{D}$ as the dependent variable adjusting for age. Lastly, we applied a sensitivity analysis, excluding subjects taking oral $25(\mathrm{OH}) \mathrm{D}$ supplements. All analyses were performed using SPSS version 20. Absolute numbers and percentages were used to describe categorical variables; means and standard deviations (SD) were used for normally distributed continuous variables.

\section{Results}

3.1. Prevalence of $25(\mathrm{OH}) \mathrm{D}$ Levels across Population. Baseline characteristics of study participants are reported in Table 1. Sixteen subjects (13 females and 3 males) reported taking vitamin D supplements. 
TABLE 1: Baseline characteristics of study participants: 600 males and 600 females (aged 25-74 years).

\begin{tabular}{|c|c|c|c|}
\hline Variables & $\begin{array}{c}\text { All } \\
N=1200\end{array}$ & $\begin{array}{c}\text { Males } \\
N=600\end{array}$ & $\begin{array}{l}\text { Females } \\
N=600\end{array}$ \\
\hline $\begin{array}{l}25(\mathrm{OH}) \mathrm{D} \text { mean } \pm \mathrm{SD} \\
(\mathrm{ng} / \mathrm{ml})\end{array}$ & $19.8 \pm 9.3$ & $20 \pm 8.5$ & $19.6 \pm 9.6$ \\
\hline Weight $(\mathrm{kg})$ & $75.7 \pm 15.7$ & $81.9 \pm 14.3$ & $69.4 \pm 14.4$ \\
\hline Height (meters) & $1.64 \pm 0.1$ & $1.71 \pm 0.1$ & $1.57 \pm 0.1$ \\
\hline Body mass index $\left(\mathrm{kg} / \mathrm{m}^{2}\right)$ & $28.1 \pm 5.3$ & $28.1 \pm 4.6$ & $28.1 \pm 5.9$ \\
\hline $\begin{array}{l}\text { Metabolic } \\
\text { syndrome-NCEP (\%) }\end{array}$ & 28.8 & 31.7 & 25.8 \\
\hline $\begin{array}{l}\text { Metabolic } \\
\text { syndrome-IDF (\%) }\end{array}$ & 40.8 & 46.8 & 34.8 \\
\hline $\mathrm{HDL}(\mathrm{mg} / \mathrm{dl})$ & $53.8 \pm 12.7$ & $48.8 \pm 11$ & $58.7 \pm 12.3$ \\
\hline $\mathrm{LDL}(\mathrm{mg} / \mathrm{dl})$ & $123.9 \pm 34.8$ & $124.5 \pm 35.7$ & $123.2 \pm 34$ \\
\hline Non-HDL (mg/dl) & $148.5 \pm 38.8$ & $152.1 \pm 38.7$ & $144.8 \pm 38.7$ \\
\hline Triglycerides (mg/dl) & $123 \pm 77.7$ & $138 \pm 92.4$ & $108.1 \pm 55.8$ \\
\hline Glycemia & $101.9 \pm 27.6$ & $105.2 \pm 29.8$ & $98.5 \pm 24.7$ \\
\hline Serum uric acid (mg/dl) & $5.3 \pm 1.5$ & $6 \pm 1.3$ & $4.6 \pm 1.2$ \\
\hline Serum insulin $(\mathrm{mg} / \mathrm{dl})$ & $9.2 \pm 14.1$ & $9 \pm 10.7$ & $9.5 \pm 16.8$ \\
\hline Creatinine (mg/dl) & $1 \pm 0.2$ & $1.1 \pm 0.2$ & $0.91 \pm 0.1$ \\
\hline $\mathrm{C} 3$ (mg/dl) & $127.4 \pm 21.1$ & $127.4 \pm 19.1$ & $127.4 \pm 23$ \\
\hline $\begin{array}{l}\text { C-reactive protein }(\mathrm{mg} / \\
\mathrm{L})\end{array}$ & $0.3 \pm 0.6$ & $0.3 \pm 0.7$ & $0.3 \pm 0.4$ \\
\hline Hemoglobin (g/dl) & $14.1 \pm 1.4$ & $15 \pm 1.1$ & $13.3 \pm 1.2$ \\
\hline $\begin{array}{l}\text { White blood cells }\left(10^{3} /\right. \\
\mu \mathrm{L})\end{array}$ & $6.4 \pm 1.6$ & $6.6 \pm 1.5$ & $6.2 \pm 1.7$ \\
\hline Smokers & $29.1 \%$ & $31.2 \%$ & $27 \%$ \\
\hline $\begin{array}{l}\text { Carbon oxide (parts per } \\
\text { million) }\end{array}$ & $3.8 \pm 6.2$ & $4.2 \pm 6.6$ & $3.3 \pm 5.8$ \\
\hline $\begin{array}{l}\text { Systolic blood pressure } \\
(\mathrm{mmHg})\end{array}$ & $137.2 \pm 20.9$ & $143.1 \pm 19$ & $131.4 \pm 20$ \\
\hline $\begin{array}{l}\text { Diastolic blood pressure } \\
(\mathrm{mmHg})\end{array}$ & $77.3 \pm 10.9$ & $79.6 \pm 10.7$ & $74.9 \pm 10.5$ \\
\hline Depression score & $7.8 \pm 7.6$ & $6.3 \pm 6.4$ & $9.2 \pm 8.4$ \\
\hline Anxiety score & $37.8 \pm 10.4$ & $35.5 \pm 9.5$ & $40 \pm 10.7$ \\
\hline $\begin{array}{l}\text { Heart rate (beats/ } \\
\text { minute) }\end{array}$ & $66.4 \pm 10.2$ & $65.4 \pm 10.3$ & $67.5 \pm 10$ \\
\hline QRS (milliseconds) & $90.8 \pm 13.1$ & $95.2 \pm 13.4$ & $86.4 \pm 11.2$ \\
\hline PR (milliseconds) & $152.4 \pm 30.5$ & $157.7 \pm 35.8$ & $147.1 \pm 23.1$ \\
\hline QT (milliseconds) & $403 \pm 29.8$ & $401.1 \pm 31.7$ & $404.8 \pm 27.8$ \\
\hline cQT (milliseconds) & $419.3 \pm 27.3$ & $413.1 \pm 30.4$ & $425.5 \pm 22.3$ \\
\hline
\end{tabular}

Percentages were used to describe categorical variables; means and standard deviations were used for continuous variables. 25(OH)D: vitamin D; SD: standard deviation; NCEP: National Cholesterol Education Program; IDF: International Diabetes Federation; HDL: high-density lipoprotein; LDL: low-density lipoprotein.

Serum 25(OH)D concentrations were $19.6 \pm 9.6 \mathrm{ng} / \mathrm{ml}$ in females and $20 \pm 8.5 \mathrm{ng} / \mathrm{ml}$ in males (NS). No statistical difference of $25(\mathrm{OH}) \mathrm{D}$ levels was observed across different decades of age (Table 2). As reported in Table 3, only 13.3\% of females and $11.1 \%$ of males had adequate concentrations of $25(\mathrm{OH}) \mathrm{D}$ ( $\geq 30 \mathrm{ng} / \mathrm{ml})$, compared to $59.3 \%$ of females and $55.1 \%$ of males who had $25(\mathrm{OH}) \mathrm{D}$ deficient $(<20 \mathrm{ng} / \mathrm{ml})$ and severe deficient $(<10 \mathrm{ng} / \mathrm{ml})$ levels.

3.2. 25(OH)D Levels and CCV Risk Factors. By subdividing patients in tertiles based on the concentration of $25(\mathrm{OH}) \mathrm{D}$ (Table 4), subjects of the lowest and highest tertiles showed significant differences in BMI, metabolic syndrome, systolic
TABLE 2: Mean and standard deviation (SD) of serum levels of 25$(\mathrm{OH}) \mathrm{D}(\mathrm{ng} / \mathrm{ml})$ in females and males according to different age groups.

\begin{tabular}{lccccc}
\hline Age & $N$ & Females & $N$ & Males & $p$ value \\
\hline $25-34$ & 120 & $20.6 \pm 8.1$ & 120 & $19.2 \pm 7.9$ & NS \\
$35-44$ & 120 & $20.3 \pm 9.3$ & 120 & $22.2 \pm 7.8$ & NS \\
$45-54$ & 120 & $18.6 \pm 9.1$ & 120 & $20.1 \pm 7.7$ & NS \\
$55-64$ & 120 & $19.2 \pm 9.5$ & 120 & $20 \pm 10$ & NS \\
$65-74$ & 120 & $19.5 \pm 11.5$ & 120 & $18.7 \pm 8.4$ & NS \\
Total & 600 & $19.6 \pm 9.6$ & 600 & $20 \pm 8.5$ & NS \\
\hline
\end{tabular}

$N$ : number; SD: standard deviation; NS: nonsignificant.

blood pressure, LDL cholesterol, non-HDL cholesterol, glycemia, CRP, C3, and cQT. Furthermore, metabolic syndrome, systolic blood pressure, CRP, and glycemia were statistically different between the lowest and the intermediate tertiles, while metabolic syndrome and non-HDL cholesterol were different between the intermediate and the highest ones.

Results of the multiple linear regression analysis are shown in Table 5. When multiple regression analysis included all CCV risk factors (BMI, metabolic syndrome score, systolic blood pressure, LDL cholesterol, non-HDL cholesterol, glycemia, CRP, C3, and cQT), an independent association between 25(OH)D and NCEP metabolic syndrome score, LDL cholesterol, HDL cholesterol, and cQT was found (Table 5). In order to better understand if the burden of each variable of the metabolic syndrome score could have an independent association with $25(\mathrm{OH}) \mathrm{D}$, we repeated the multivariate model without metabolic syndrome score and we observed a significant independent association with BMI, HDL cholesterol, non-HDL cholesterol, glycemia, and cQT (Table 6). The sensitivity analysis, carried out excluding subjects taking oral vitamin D supplements, did not modify the results obtained with the whole cohort.

\section{Discussion}

In this study, we first reported epidemiological data of serum $25(\mathrm{OH}) \mathrm{D}$ levels from the largest adult Italian population studied so far and across Southern Italy. Surprisingly, and confuting our initial hypothesis, we found a large prevalence of vitamin $\mathrm{D}$ deficiency among our population sample. In fact, despite the low latitude, according to studies conducted in the Northern Europe and North America [40, 41], 57.2\% of our cohort showed 25(OH)D values lower than $20 \mathrm{ng} / \mathrm{ml}$, while only $12.2 \%$ showed values between 30 and $100 \mathrm{ng} / \mathrm{ml}$, considering the normal range by national and international guidelines [30, 31]. No significant dissimilarity of $25(\mathrm{OH}) \mathrm{D}$ levels was found between different decade groups and gender $(19.6 \pm 9.6 \mathrm{ng} / \mathrm{ml}$ in females and $20 \pm 8.5 \mathrm{ng} / \mathrm{ml}$ in males).

These results are probably due to less sunlight exposure, independently of age and sex, mainly for social reasons and for skin cancer prevention [14], highlighting that actual sunlight exposure affects serum 25(OH)D levels more than simple latitude. Considering that vitamin $\mathrm{D}$ deficiency has 
TABle 3: Prevalence of different vitamin D nutritional statuses: severe deficient, deficient, insufficiency, and normal values in females and males.

\begin{tabular}{lcccc}
\hline Reference range & Females, $N$ & Prevalence (\%) & Males, $N$ & Prevalence (\%) \\
\hline Severe deficient: $<10 \mathrm{ng} / \mathrm{mL}$ & 80 & 13.3 & 57 & 9.5 \\
Deficient: $\geq 10<20 \mathrm{ng} / \mathrm{mL}$ & 276 & 46 & 273 & 45.6 \\
Insufficiency: $\geq 20<30 \mathrm{ng} / \mathrm{mL}$ & 164 & 27.4 & 203 & 33.8 \\
Normal: $\geq 30 \mathrm{ng} / \mathrm{mL}$ & 80 & 13.3 & 67 & 11.1 \\
\hline
\end{tabular}

$N$ : number.

TABle 4: Differences of 25(OH)D tertiles in demographical, clinical, and laboratory variables.

\begin{tabular}{|c|c|c|c|c|c|c|c|}
\hline \multirow{2}{*}{ Variables } & \multirow{2}{*}{$\begin{array}{l}\text { I tertile } \\
N=400\end{array}$} & \multirow{2}{*}{$\begin{array}{l}\text { II tertile } \\
N=400\end{array}$} & \multirow{2}{*}{$\begin{array}{l}\text { III tertile } \\
N=400\end{array}$} & \multirow{2}{*}{$p$} & \multicolumn{3}{|c|}{$t$} \\
\hline & & & & & I vs. II & I vs. III & II vs. III \\
\hline $25(\mathrm{OH}) \mathrm{D}$ range $(\mathrm{ng} / \mathrm{ml})$ & $3.7-15.0$ & $15.1-22.3$ & $22.4-64.3$ & - & - & - & - \\
\hline $25(\mathrm{OH}) \mathrm{D}$ mean $\pm \mathrm{SD}(\mathrm{ng} / \mathrm{ml})$ & $10.9 \pm 2.6$ & $18.5 \pm 2.1$ & $30.1 \pm 7.0$ & - & - & - & - \\
\hline Age (years) & $51.5 \pm 14.1$ & $48 \pm 14.1$ & $48.4 \pm 13.8$ & 0.001 & $2.6^{*}$ & $2.4^{*}$ & 1.8 \\
\hline Males (\%) & $46.6 \%$ & 49.5 & 52.6 & NS & - & - & - \\
\hline \multicolumn{8}{|l|}{ Anthropometric variables } \\
\hline Weight $(\mathrm{kg})$ & $75.7 \pm 17$ & $76.4 \pm 15.8$ & $74.6 \pm 14.3$ & NS & - & - & - \\
\hline Height (meters) & $1.63 \pm 0.1$ & $1.65 \pm 0.1$ & $1.65 \pm 0.1$ & NS & - & - & - \\
\hline Body mass index $\left(\mathrm{kg} / \mathrm{m}^{2}\right)$ & $28.7 \pm 6.0$ & $28.2 \pm 5.3$ & $27.4 \pm 4.4$ & 0.006 & 1.2 & $3.2^{*}$ & 2.0 \\
\hline Metabolic syndrome-NCEP (\%) & 34.5 & 31.7 & 20.4 & $<0.001$ & - & - & - \\
\hline Metabolic syndrome-IDF (\%) & 44.8 & 42.5 & 35.3 & 0.02 & - & - & - \\
\hline \multicolumn{8}{|l|}{ Serum variables } \\
\hline HDL cholesterol (mg/dl) & $52.9 \pm 12.6$ & $53.4 \pm 12.6$ & $55.1 \pm 12.8$ & NS & - & - & - \\
\hline LDL cholesterol(mg/dl) & $127 \pm 35.2$ & $125.5 \pm 34.4$ & $119.8 \pm 34.8$ & 0.02 & 0.6 & $2.7^{*}$ & 2.1 \\
\hline Non-HDL cholesterol (mg/dl) & $152.4 \pm 38.7$ & $150.5 \pm 39$ & $142.8 \pm 38.2$ & 0.003 & 0.6 & $3.2^{*}$ & $2.6 *$ \\
\hline Triglycerides (mg/dl) & $127 \pm 82.3$ & $126.8 \pm 73.9$ & $114.8 \pm 77.1$ & 0.04 & 2.0 & 2.0 & - \\
\hline Glycemia & $106.4 \pm 36.2$ & $100.2 \pm 24.3$ & $99.3 \pm 20.2$ & 0.001 & $2.9^{*}$ & $3.3^{*}$ & 0.4 \\
\hline Serum uric acid (mg/dl) & $5.2 \pm 1.5$ & $5.3 \pm 1.5$ & $5.3 \pm 1.4$ & NS & - & - & - \\
\hline Serum insulin $(\mathrm{mg} / \mathrm{dl})$ & $9.8 \pm 15.3$ & $10.2 \pm 18$ & $7.9 \pm 6.4$ & NS & - & - & - \\
\hline Creatinine $(\mathrm{mg} / \mathrm{dl})$ & $1.0 \pm 0.2$ & $1.0 \pm 0.2$ & $1.0 \pm 0.2$ & NS & - & - & - \\
\hline $\mathrm{C} 3(\mathrm{mg} / \mathrm{dl})$ & $128.9 \pm 20.9$ & $128.7 \pm 21.9$ & $124.9 \pm 20.6$ & 0.02 & 0.1 & $2.5^{*}$ & 2.3 \\
\hline C-reactive protein $(\mathrm{mg} / \mathrm{L})$ & $0.4 \pm 0.8$ & $0.3 \pm 0.4$ & $0.3 \pm 0.5$ & 0.04 & $2.2^{*}$ & $2.1^{*}$ & 0.2 \\
\hline Hemoglobin $(\mathrm{g} / \mathrm{dl})$ & $14.1 \pm 1.5$ & $14.1 \pm 1.4$ & $14.1 \pm 1.4$ & NS & - & - & - \\
\hline White blood cells $\left(10^{3} / \mu / \mathrm{L}\right)$ & $6.5 \pm 1.7$ & $6.5 \pm 1.6$ & $6.3 \pm 1.5$ & NS & - & - & \\
\hline \multicolumn{8}{|l|}{ Others CCV risk factors } \\
\hline Carbon oxide (parts per million) & $4.4 \pm 7.2$ & $3.6 \pm 5.9$ & $3.4 \pm 5.5$ & NS & - & - & - \\
\hline Systolic blood pressure (mmHg) & $140.2 \pm 21.9$ & $135.4 \pm 20.9$ & $135.7 \pm 19.4$ & 0.004 & $3.0^{*}$ & $2.3^{*}$ & 0.2 \\
\hline Diastolic blood pressure (mmHg) & $78.3 \pm 11.3$ & $76.7 \pm 10.8$ & $76.8 \pm 10.3$ & NS & - & - & - \\
\hline \multicolumn{8}{|l|}{ Psychological variables } \\
\hline Depression score & $8.3 \pm 7.9$ & $7.6 \pm 8$ & $7.7 \pm 6.9$ & NS & - & - & - \\
\hline Anxiety score & $38.5 \pm 11.2$ & $37.2 \pm 9$ & $37.8 \pm 9.9$ & NS & - & - & - \\
\hline \multicolumn{8}{|l|}{ ECG variables } \\
\hline Heart rate (beats/minute) & $67.3 \pm 11.2$ & $66.2 \pm 9.4$ & $66 \pm 9.6$ & NS & - & - & - \\
\hline QRS (milliseconds) & $91 \pm 15.2$ & $90.3 \pm 11.8$ & $90.9 \pm 12$ & NS & - & - & - \\
\hline PR (milliseconds) & $151.1 \pm 24$ & $152.7 \pm 30.4$ & $152.7 \pm 25.1$ & NS & - & - & - \\
\hline QT (milliseconds) & $402.7 \pm 30.2$ & $403.5 \pm 27.7$ & $402.1 \pm 31.3$ & NS & - & - & - \\
\hline cQT (milliseconds) & $421.6 \pm 30.3$ & $419.8 \pm 22$ & $416.5 \pm 28.6$ & 0.03 & 1.8 & $2.5^{*}$ & 1.8 \\
\hline
\end{tabular}

Absolute numbers \{range (min-max)\} and percentage were used to describe categorical variables; means and standard deviations (SD) were used for continuous variables. Statistical significance was accepted for values of $p<0.05$; NS: nonsignificant; $t$ : $t$-value (Bonferroni test). * Significant difference $(p<0,05)$ at Bonferroni test. 25(OH)D: vitamin D; NCEP: National Cholesterol Education Program; IDF: International Diabetes Federation.

been increasingly demonstrated to be an independent CCV risk factor, we investigated its relationship with major $\mathrm{CCV}$ risk factors using tertile-based categories.

Patients in the highest tertile $(25(\mathrm{OH}) \mathrm{D}$ levels $>22,4 \mathrm{ng} /$ $\mathrm{ml}$ ) had lower CCV risk, compared to those in the intermediate or lowest tertile, due to significantly better profiles of BMI, systolic blood pressure, metabolic syndrome, HDL cholesterol, LDL cholesterol, non-HDL cholesterol, triglycerides, glycemia, cQT, CRP, and C3. Furthermore, we found an independent association between $25(\mathrm{OH}) \mathrm{D}$ and each of the following variables: NCEP metabolic syndrome score, LDL cholesterol, HDL cholesterol, and cQT. 
TABle 5: Multivariate analysis. Multiple linear regression model (stepwise procedure) with $25(\mathrm{OH}) \mathrm{D}$ as the dependent variable and body mass index (BMI), metabolic syndrome score of the National Cholesterol Education Program (NCEP), metabolic syndrome score of the International Diabetes Federation (IDF), systolic blood pressure, LDL cholesterol, non-HDL cholesterol, glycemia, CRP, $\mathrm{C} 3$, and QTc.

\begin{tabular}{lcc}
\hline Variable & Beta & $p$ \\
\hline Metabolic syndrome score-NCEP & -0.092 & 0.005 \\
QTc & -0.007 & 0.002 \\
LDL cholesterol (mg/dl) & -0.094 & 0.001 \\
HDL (mg/dl) & 0.083 & 0.012
\end{tabular}

Statistical significance was accepted for values of $p<0.05$.

TABLe 6: Multivariate analysis. Multiple linear regression model (stepwise procedure) without metabolic syndrome score: $25(\mathrm{OH}) \mathrm{D}$ as the dependent variable and body mass index (BMI), systolic blood pressure, LDL cholesterol, non-HDL cholesterol, glycemia, CRP, C3, and QTc.

\begin{tabular}{lcc}
\hline Variable & Beta & $p$ \\
\hline BMI & -0.072 & 0.021 \\
QTC & -0.066 & 0.026 \\
Non-HDL cholesterol (mg/dl) & -0.094 & 0.001 \\
HDL (mg/dl) & 0.081 & 0.08 \\
Glycemia (mg/dl) & -0.063 & 0.038 \\
\hline
\end{tabular}

Statistical significance was accepted for values of $p<0.05$.

Furthermore, removing metabolic syndrome score from the regression model, also BMI and glycemia were observed as independent predictors.

The inverse relationship between $25(\mathrm{OH}) \mathrm{D}$ and $\mathrm{BMI}$ has been established in various studies and, especially, in a study involving 42024 participants from 21 cohorts [14]; subsequently, it was also confirmed in cohorts of children and adolescents [42, 43] and in numerous ethnic groups [44]. A possible explanation of this finding could be the fact that obese individuals get insufficient sun exposure, perform less outdoor activities [42], and present lower $1,25(\mathrm{OH})_{2} \mathrm{D}$ receptor expression in adipose tissue [43]. Having this in mind, we can speculate that population-level interventions to reduce BMI are expected to decrease the prevalence of vitamin D deficiency; therefore, studies focused on this specific aim could be an interesting research topic. Secondly, the inverse and independent association found between $25(\mathrm{OH}) \mathrm{D}$ and glycemia is also relevant; in fact, this finding adds evidence to previous studies that showed better glycemic conditions in subjects with higher 25(OH)D levels $[44,45]$. This association is particularly interesting considering that vitamin $\mathrm{D}$ supplementation seems to reduce type 1 diabetes mellitus incidence in childhood [46, 47] and to prevent the development and severity of peripheral neuropathy in patients with type 2 diabetes mellitus $[48,49]$. These data do not support a direct cause-and-effect relationship, and indeed a recent prospective analysis provided results on the noncausal association between vitamin $\mathrm{D}$ and risk of type-2 diabetes, taking into account genetics as well [50]. Further studies are thus warranted.
Regarding the relationship between 25(OH)D and lipid profile, we found an inverse association between $25(\mathrm{OH}) \mathrm{D}$ levels and LDL cholesterol, non-HDL cholesterol, and a direct association between 25(OH)D and HDL [51-54], confirming previous studies. Various mechanisms have been suggested to explain the relation between $25(\mathrm{OH}) \mathrm{D}$ and lipid metabolism: (i) vitamin D and its metabolites play a role in cholesterol synthesis inhibiting 3-hydroxy-3methyl-glutaryl-CoA-reductase and lanosterol 14a-demethylase enzyme activity in cultured cells [55]; (ii) lower LDL-C concentrations have been observed in people with higher sunlight exposure, although it is not known whether the exposure to sunlight affects cholesterol metabolism indirectly, by improving the status of vitamin $\mathrm{D}$, or directly; (iii) vitamin $\mathrm{D}$ is essential to maintain the necessary levels of apolipoprotein A-1, the main component of $\mathrm{HDL}$ [56].

Finally, it is interesting to examine the indirect association between cQT and 25(OH)D levels found in our sample. In fact, very little is known about the relationship between cQT and 25(OH)D with contrasting results. Nalbant et al. demonstrated that there is no difference in cQT between people with normal levels of $25(\mathrm{OH}) \mathrm{D}$ and those with low levels of 25(OH)D [57]; on the other hand, prolonged cQT duration and $\mathrm{CQT}$ dispersion have been observed in patients with vitamin D deficiency [57-59].

However, our study is not without limitations: (i) the cohort studied was selected from two small municipalities in Southern Italy and could not be representative of the whole population in Italy and Southern Italy; (ii) we conducted the study in a time span of 18 months (January 2018-July 2019), with a possible impact of seasonal variations of vitamin $D$; (iii) due to the cross-sectional nature of the study, reverse causation could not be excluded.

In conclusion, we found a high prevalence of vitamin D deficiency across the largest Italian population studied so far; furthermore, we provided data of an association between vitamin D deficiency and higher CCV risk factors. These results provide evidence to better select the correct targeting population subgroups that may benefit from vitamin D supplementation. In fact, since now, randomized controlled trials (RCTs) have shown ambiguous results about the efficacy of vitamin $\mathrm{D}$ supplementation in reducing major CCV events [60-63]; this may partly be explained by taking into account the fact that heterogeneous samples were selected or that different $25(\mathrm{OH}) \mathrm{D}$ doses and analogs were used [64].

\section{Abbreviations}

25(OH)D: Vitamin D

CCV: Cardio-cerebrovascular

ECG: Electrocardiogram

BMI: $\quad$ Body mass index

NCEP: National cholesterol educational program

IDF: International Diabetes Federation

CRP: $\quad$ C-reactive protein

cQT: $\quad$ Correct QT. 


\section{Data Availability}

The data are stored in an internal archive, and most of the data have been shared with the NCD Risk Factor Collaboration (NCD-RisC) group.

\section{Conflicts of Interest}

The authors declare that they have no conflicts of interest.

\section{References}

[1] S. Christakos, P. Dhawan, A. Verstuyf, L. Verlinden, and G. Carmeliet, "Vitamin D: metabolism, molecular mechanism of action, and pleiotropic effects," Physiological Reviews, vol. 96, pp. 365-408, 2015.

[2] T. O. Carpenter, N. J. Shaw, A. A. Portale, L. M. Ward, S. A. Abrams, and J. M. Pettifor, "Rickets," Nature Reviews Disease Primers, vol. 3, 2017.

[3] S. Uday, N. Fratzl-Zelman, P. Roschger et al., "Cardiac, bone and growth plate manifestations in hypocalcemic infants: revealing the hidden body of the vitamin $\mathrm{D}$ deficiency iceberg," BMC Pediatrics, vol. 18, no. 1, p. 183, 2018.

[4] S. Uday and W. Högler, "Nutritional rickets and osteomalacia in the twenty-first century: revised concepts, public health, and prevention strategies," Current Osteoporosis Reports, vol. 15, no. 4, pp. 293-302, 2017.

[5] M. Aguiar, N. Atapattu, V. Bhatia et al., "Global consensus recommendations on prevention and management of nutritional rickets," The Journal of Clinical Endocrinology and Metabolism, vol. 101, pp. 394-415, 2016.

[6] R. Bouillon, G. Carmeliet, L. Verlinden et al., "Vitamin D and human health: lessons from vitamin D receptor null mice," Endocrine Reviews, vol. 29, no. 6, pp. 726-776, 2008.

[7] C. J. Rosen, J. S. Adams, D. D. Bikle et al., "The nonskeletal effects of vitamin D: an endocrine society scientific statement," Endocrine Reviews, vol. 33, no. 3, pp. 456-492, 2012.

[8] S. Pilz, N. Verheyen, M. R. Grübler, A. Tomaschitz, and W. März, "Vitamin D and cardiovascular disease prevention," Nature Reviews Cardiology, vol. 13, no. 7, pp. 404-417, 2016.

[9] C. Trummer, S. Pilz, V. Schwetz, B. Obermayer-Pietsch, and E. Lerchbaum, "Vitamin D, PCOS and androgens in men: a systematic review," Endocrine Connections, vol. 7, no. 3, pp. R95-R113, 2018.

[10] G. Muscogiuri, B. Altieri, C. Annweiler et al., "Vitamin D and chronic diseases: the current state of the art," Archives of Toxicology, vol. 91, no. 1, pp. 97-107, 2017.

[11] A. Zittermann, S. Pilz, H. Hoffmann, and W. März, "Vitamin D and airway infections: a European perspective," European Journal of Medical Research, vol. 21, p. 14, 2016.

[12] C. L. Wagner and B. W. Hollis, "The implications of vitamin D status during pregnancy on mother and her developing child," Frontiers in Endocrinology, vol. 9, p. 500, 2018.

[13] J. T. Keane, H. Elangovan, R. A. Stokes, and J. E. Gunton, "Vitamin D and the liver-correlation or cause?" Nutrients, vol. 10, 2018.

[14] L. Alfredsson, B. K. Armstrong, D. A. Butterfield et al., "Insufficient sun exposure has become a real public health problem," International Journal of Environmental Research and Public Health, vol. 17, pp. 1-15, 2020.

[15] A. Burgaz, N. Orsini, S. C. Larsson, and A. Wolk, "Blood 25hydroxyvitamin D concentration and hypertension: a metaanalysis," Journal of Hypertension, vol. 29, no. 4, pp. 636-645, 2011.
[16] S. K. Syal, A. Kapoor, E. Bhatia et al., "Vitamin D deficiency, coronary artery disease, and endothelial dysfunction: observations from a coronary angiographic study in Indian patients," The Journal of Invasive Cardiology, vol. 24, pp. 385-389, 2012.

[17] T. J. Wang, M. J. Pencina, S. L. Booth et al., "Vitamin D deficiency and risk of cardiovascular disease," Circulation, vol. 117 , no. 4 , pp. 503-511, 2008.

[18] D. Duplancic, M. Cesarik, N. K. Poljak et al., "The influence of selective vitamin D receptor activator paricalcitol on cardiovascular system and cardiorenal protection," Clinical Interventions in Aging, vol. 8, pp. 149-156, 2013.

[19] M. B. Elamin, N. O. Abu Elnour, K. B. Elamin et al., "Vitamin $\mathrm{D}$ and cardiovascular outcomes: a systematic review and meta-analysis," The Journal of Clinical Endocrinology \& Metabolism, vol. 96, no. 7, pp. 1931-1942, 2011.

[20] H. Dobnig, S. Pilz, H. Scharnagl et al., "Independent association of low serum 25-hydroxyvitamin D and 1,25-dihydroxyvitamin D levels with all-cause and cardiovascular mortality," Archives of Internal Medicine, vol. 168, no. 12, pp. 1340-1349, 2008.

[21] W. R. Chen, Y. A. Qian, Y. D. Chen et al., "The effects of low vitamin D on coronary artery disease," Heart, Lung and Circulation, vol. 23, no. 4, pp. 314-319, 2014.

[22] J. J. Hsu, Y. Tintut, and L. L. Demer, "Vitamin D and osteogenic differentiation in the artery wall," Clinical Journal of the American Society of Nephrology, vol. 3, no. 5, pp. 1542$1547,2008$.

[23] M. Liberman, A. E. P. Pesaro, L. S. Carmo, and C. V. Serrano Jr, "Calcificação vascular: fisiopatologia e implicações clínicas,” Einstein (São Paulo), vol. 11, no. 3, pp. 376-382, 2013.

[24] M. De Metrio, V. Milazzo, M. Rubino et al., "Vitamin D plasma levels and in-hospital and 1-year outcomes in acute coronary syndromes," Medicine (United States), vol. 94, 2015.

[25] L. L. Ng, J. K. Sandhu, I. B. Squire, J. E. Davies, and D. J. L. Jones, "Vitamin D and prognosis in acute myocardial infarction," International Journal of Cardiology, vol. 168, no. 3, pp. 2341-2346, 2013.

[26] A. Aleksova, R. Belfiore, C. Carriere et al., "Vitamin D deficiency in patients with acute myocardial infarction: an italian single-center study," International Journal for Vitamin and Nutrition Research, vol. 85, no. 1-2, pp. 23-30, 2015.

[27] I. Gouni-Berthold, W. Krone, and H. Berthold, "Vitamin D and cardiovascular disease," Current Vascular Pharmacology, vol. 7, no. 3, pp. 414-422, 2009.

[28] A. Talebi, A. Amirabadizadeh, S. Nakhaee, Z. Ahmadi, and S. M. Mousavi-Mirzaei, "Cerebrovascular disease: how serum phosphorus, vitamin D, and uric acid levels contribute to the ischemic stroke," BMC Neurology, vol. 20, no. 1, p. 116, 2020.

[29] B. P. Berghout, L. Fani, A. Heshmatollah et al., "Vitamin D status and risk of stroke," Stroke, vol. 50, no. 9, pp. 2293-2298, 2019.

[30] R. Cesareo, R. Attanasio, M. Caputo et al., "Italian association of clinical endocrinologists (AME) and Italian chapter of the American association of clinical endocrinologists (AACE) position statement: clinical management of vitamin $\mathrm{D}$ deficiency in adults," Nutrients, vol. 10, 2018.

[31] M. F. Holick, N. C. Binkley, H. A. Bischoff-Ferrari et al., "Evaluation, treatment, and prevention of vitamin D deficiency: an endocrine society clinical practice guideline," The Journal of Clinical Endocrinology \& Metabolism, vol. 96, no. 7, pp. 1911-1930, 2011.

[32] A. a. Alkerwi, N. Sauvageot, G. Gilson, and S. Stranges, "Prevalence and correlates of vitamin D deficiency and 
insufficiency in Luxembourg adults: evidence from the observation of cardiovascular risk factors (ORISCAV-LUX) study," Nutrients, vol. 7, no. 8, pp. 6780-6796, 2015.

[33] S. Vandevijvere, S. Amsalkhir, H. van Oyen, and R. MorenoReyes, "High prevalence of vitamin D deficiency in pregnant women: a national cross-sectional survey," PLoS One, vol. 7, Article ID e43868, 2012.

[34] P. Lips, "Vitamin D status and nutrition in Europe and asia," The Journal of Steroid Biochemistry and Molecular Biology, vol. 103, no. 3-5, pp. 620-625, 2007.

[35] C. V. Harinarayan, "Prevalence of vitamin D insufficiency in postmenopausal south Indian women," Osteoporosis International, vol. 16, no. 4, pp. 397-402, 2005.

[36] V. Capuano, T. D'arminio, A. Bambacaro, and C. D. V. Lanzara, "Il Progetto VIP: prevalenza dei fattori di rischio della cardiopatia ischemica in un'area della Campania," Italian Heart Journal, vol. 2, no. 11, pp. 1201-1208, 2001.

[37] A. Menotti, S. Giampaoli, A. Verdecchia et al., Il Progetto MONICA (Monitoraggio Malattie Cardiovascolari), Protocollo e Manuale Delle Aree Italiane, Rapporto 1989, Roma: Istituto Superiore di Sanita, 1989, (Rapporti ISTISAN 89/12).

[38] G. A. Rose and H. Blackburn, "Cardiovascular survey methods," in Monograph Series, pp. 1-188, World Health Organization, Geneva, Switzerland, 1968.

[39] C. Lorenzo, K. Williams, K. J. Hunt, and S. M. Haffner, "The national cholesterol education program-adult treatment panel III, international diabetes federation, and World health organization definitions of the metabolic syndrome as predictors of incident cardiovascular disease and diabetes," Diabetes Care, vol. 30, no. 1, pp. 8-13, 2007.

[40] M. F. Holick, "High prevalence of vitamin D inadequacy and implications for health," Mayo Clinic Proceedings, vol. 81, no. 3, pp. 353-373, 2006.

[41] L. S. Greene-Finestone, C. Berger, C. Berger et al., "25Hydroxyvitamin D in Canadian adults: biological, environmental, and behavioral correlates," Osteoporosis International, vol. 22, no. 5, pp. 1389-1399, 2011.

[42] M. Pereira-Santos, P. R. F. Costa, A. M. O. Assis, C. A. S. T. Santos, and D. B. Santos, "Obesity and vitamin D deficiency: a systematic review and meta-analysis," Obesity Reviews, vol. 16, no. 4, pp. 341-349, 2015.

[43] K. E. Wong, J. Kong, W. Zhang et al., "Targeted expression of human vitamin $\mathrm{D}$ receptor in adipocytes decreases energy expenditure and induces obesity in mice," Journal of Biological Chemistry, vol. 286, no. 39, pp. 33804-33810, 2011.

[44] L. L. Munasinghe, M. F. Mastroeni, S. S. B. S. Mastroeni, S. A. Loehr, J. P. Ekwaru, and P. J. Veugelers, "The association of serum 25-hydroxyvitamin d concentrations and elevated glycated hemoglobin values: a longitudinal study of non-diabetic participants of a preventive health program," Nutrients, vol. 9, 2017.

[45] A. Deleskog, A. Hilding, K. Brismar, A. Hamsten, S. Efendic, and C.-G. Östenson, "Low serum 25-hydroxyvitamin D level predicts progression to type 2 diabetes in individuals with prediabetes but not with normal glucose tolerance," Diabetologia, vol. 55, no. 6, pp. 1668-1678, 2012.

[46] L. C. Stene, J. Ulriksen, P. Magnus, and G. Joner, "Use of cod liver oil during pregnancy associated with lower risk of Type I diabetes in the offspring," Diabetologia, vol. 43, no. 9, pp. 1093-1098, 2000.

[47] E. Hyppönen, E. Läärä, A. Reunanen, M.-R. Järvelin, and S. M. Virtanen, "Intake of vitamin D and risk of type 1 diabetes: a birth-cohort study," The Lancet, vol. 358, no. 9292, pp. 1500-1503, 2001.
[48] B. Zhang, W. Zhao, J. Tu et al., "The relationship between serum 25-hydroxyvitamin $\mathrm{D}$ concentration and type 2 diabetic peripheral neuropathy: A systematic review and a metaanalysis," Medical (United States), vol. 98, 2019.

[49] U. Alam, A. Fawwad, F. Shaheen, B. Tahir, A. Basit, and R. A. Malik, "Improvement in neuropathy specific quality of life in patients with diabetes after vitamin D supplementation," Journal of Diabetes Research, vol. 2017, Article ID 7928083, 7 pages, 2017.

[50] J. S. Zheng, J. Luan, E. Sofianopoulou et al., "The association between circulating 25-hydroxyvitamin D metabolites and type 2 diabetes in European populations: a meta-analysis and Mendelian randomisation analysis," PLoS Medicine, vol. 17, Article ID e1003394, 2020.

[51] A. Yarparvar, I. Elmadfa, A. Djazayery, Z. Abdollahi, and F. Salehi, "The association of vitamin d status with lipid profile and inflammation biomarkers in healthy adolescents," $\mathrm{Nu}$ trients, vol. 12, 2020.

[52] S. N. Saeidlou, D. Vahabzadeh, F. Babaei, and Z. Vahabzadeh, "Seasonal variations of vitamin D and its relation to lipid profile in Iranian children and adults," Journal of Health, Population and Nutrition, vol. 36, 2017.

[53] E. Rashidbeygi, M. H. Rahimi, M. Mollahosseini et al., "Associations of vitamin D status and metabolic dyslipidemia and hypertriglyceridemic waist phenotype in apparently healthy adults," Diabetes \& Metabolic Syndrome: Clinical Research \& Reviews, vol. 12, no. 6, pp. 985-990, 2018.

[54] R. Kelishadi, Z. Farajzadegan, and M. Bahreynian, "Association between vitamin D status and lipid profile in children and adolescents: a systematic review and meta-analysis," International Journal of Food Sciences and Nutrition, vol. 65, no. 4, pp. 404-410, 2014.

[55] A. K. Gupta, R. C. Sexton, and H. Rudney', "Effect of vitamin D3 derivatives on cholesterol synthesis and HMG-CoA reductase activity in cultured cells," Journal of Lipid Research, vol. 30, 1989.

[56] W. G. John, K. Noonan, N. Mannan, and B. J. Boucher, "Hypovitaminosis D is associated with reductions in serum apolipoprotein A-I but not with fasting lipids in British Bangladeshis," The American Journal of Clinical Nutrition, vol. 82, no. 3, pp. 517-522, 2005.

[57] A. Nalbant, M. B. Vatan, P. VarÄ \pm m, C. VarÄ \pm m, T. Kaya, and A. Tamer, "Does vitamin D deficiency effect heart rate variability in low cardiovascular risk population?" Open Access Macedonian Journal of Medical Sciences, vol. 5, no. 2, pp. 197-200, 2017.

[58] D. O. Yetkin, B. Kucukkaya, M. Turhan, and M. Oren, "The effect of 25-hydroxyvitamin D levels on QT interval duration and dispersion in type 2 diabetic patients," Croatian Medical Journal, vol. 56, no. 6, pp. 525-530, 2015.

[59] D. Bagrul and F. Atik, "Association of Vitamin D deficiency with ventricular repolarization abnormalities," Kardiologia Polska, vol. 77, no. 9, pp. 853-858, 2019.

[60] P. Autier, M. Boniol, C. Pizot, and P. Mullie, "Vitamin D status and ill health: a systematic review," The Lancet Diabetes \& Endocrinology, vol. 2, no. 1, pp. 76-89, 2014.

[61] K. M. Swart, P. Lips, I. A. Brouwer et al., "Effects of vitamin D supplementation on markers for cardiovascular disease and type 2 diabetes: an individual participant data meta-analysis of randomized controlled trials," The American Journal of Clinical Nutrition, vol. 107, no. 6, pp. 1043-1053, 2018.

[62] P. Autier, P. Mullie, A. Macacu et al., "Effect of vitamin D supplementation on non-skeletal disorders: a systematic 
review of meta-analyses and randomised trials," The Lancet Diabetes \& Endocrinology, vol. 5, no. 12, pp. 986-1004, 2017.

[63] L. Rejnmark, L. S. Bislev, K. D. Cashman et al., "Non-skeletal health effects of Vitamin D supplementation: a systematic review on findings from meta-Analyses summarizing trial data," PLoS One, vol. 12, Article ID e0180512, 2017.

[64] C. Legarth, D. Grimm, M. Krüger, M. Infanger, and M. Wehland, "Potential beneficial effects of vitamin $d$ in coronary artery disease," Nutrients, vol. 12, no. 1, p. 99, 2019. 